\title{
Wydarzenia z lutego 1943 roku w getcie białostockim w świetle pism Mordechaja Tenenbauma-Tamarofa
}

\section{Streszczenie:}

Artykuł przedstawia wydarzenia z lutego 1943 roku w getcie w Białymstoku w oparciu o hebrajskie pisma Mordechaja Tenenbauma-Tamarofa z Podziemnego Archiwum Getta Białostockiego (Archiwum Mersika-Tenenbauma). Autorka prezentuje fragmenty z Dziennika Tenenbauma oraz z dokumentów: „Akcja” w Białymstoku i Komentarza do tegoż pisma (Hearot). Dokumenty te stanowią bardzo cenne źródła informacji o „akcji likwidacyjnej” zwanej w literaturze „pierwszą akcją” w getcie białostockim. W artykule przybliżono wątek Icchoka Malmeda, a także opis działania policji żydowskiej w białostockim getcie (jako elementy narracji Tamarofa), których analiza otwiera interesujące perspektywy dla badań nad zagadnieniami dotyczącymi „akcji lutowej”.

Słowa-klucze: getto, Białystok, luty 1943 rok, Mordechaj Tenenbaum, Tamarof, policja żydowska, Icchok Malmed.

Weronika Romanik - absolwentka kulturoznawstwa ze specjalnością hebraistyka na Uniwersytecie Warszawskim (summa cum laude), doktorantka w Zakładzie Hebraistyki na Wydziale Orientalistycznym UW, studentka socjologii i antropologii w ramach MISHiS UW ze specjalnością mediacje, negocjacje. Studiowała także na Uniwersytecie Hebrajskim w Jerozolimie, Uniwersytecie w Tel Awiwie, New York University oraz Lund University. Prowadziła zajęcia m.in. w Zakładzie Hebraistyki UW oraz Katedrze Judaistyki UWr. Od 2007 roku jako edukatorka współpracuje z Fundacją Forum Dialogu, a od 2016 roku z Fundacją Alef Bet. 


\section{February 1943 events in the Bialystok Ghetto in the light of writings by Mordechai Tenenbaum-Tamarof}

\section{Summary:}

The article presents events that took place in February 1943 in the Bialystok Ghetto based on Hebrew writings by Mordechai Tenenbaum-Tamarof from the Underground Archives of the Bialystok Ghetto (Mersik-Tenenbaum Archives). The author presents fragments of The Diary by Tenenbaum and documents: "Action" in Bialystok and a Commentary to this journal (Hearot). These documents constitute an invaluable source of information on "the liquidation action", known in literature as "the first action" in the BiaIystok Ghetto. The article outlines the life of Icchok Malmed as well as describes the activity of Jewish police in the Bialystok Ghetto (as elements of Tamarof's narration), where their analysis opens interesting perspectives for conducting research on the "February action" issue.

Key words: ghetto, Bialystok, February 1943, Mordechai Tenenbaum, Tamarof, Jewish police, Icchok Malmed.

Mordechaj Tenenbaum-Tamarof jest stosunkowo mało znaną postacią w Polsce, prawdopodobnie przede wszystkim ze względu na barierę językową, która towarzyszy recepcji jego pism - napisanych głównie po hebrajsku i nieprzetłumaczonych do tej pory w całości na język polski ani na angielski. W niniejszej pracy zaprezentuję fragmenty rękopisów Tenenbauma dotyczące ,akcji lutowej” w białostockim getcie, opierając się na jego pismach podpisanych nazwiskiem Tamarof: Dzienniku, dokumencie „Akcja” $w$ Białymstoku oraz Komentarzu do tegoż pisma1.

1 Oryginalne rękopisy Tenenbauma znajdują się w Archiwum Yad Vashem (dalej: AYV) w Jerozolimie, zob. M11/4, M11/5, M11/6. Dokumenty zostały opublikowane po hebrajsku po raz pierwszy w 1947 roku, zaś po raz drugi w poprawionej wersji w 1984 roku. Zob. Dapim min hadleka. Pirkei joman, michtawim ureszimot meet Mordechaj Tenenbojm-Tamarof, Tel Awiw 1947 (dalej: Dapim, 1947). Por. Dapim min hadleka. Mahadura chadasza, metukenet umurchewet, red. B. Klibanski, C. Szner, Izrael 1984 (dalej: Dapim, 1984). 


\section{Sylwetka Mordechaja Tenenbauma}

Biorąc pod uwagę przywódczą rolę Tenenbauma w podziemiu w trakcie ostatecznej „likwidacji” getta w Białymstoku, proponuję określanie Tamarofa mianem „Anielewicza białostockiego getta”. Podobnie zasługuje on na miano „Ringelbluma białostockiego getta”, przez wzgląd na zainicjowanie przez niego Podziemnego Archiwum Getta Białostockiego, znanego dziś jako Archiwum Mersika-Tenenbauma³.

Mordechaj Tenenbaum - nazywany przez swych bliskich Mordchajem4, urodził się w Warszawie w 1916 roku. Tu uczył się i studiował w Instytucie Orientalistycznym na Uniwersytecie Warszawskim. Przez lata był działaczem syjonistycznej organizacji Frajhajt, która później przekształciła się w Dror Hechaluc. W czasie wojny, w celu ukrycia prawdziwej tożsamości, Tenenbaum samodzielnie wyrobił fałszywe dokumenty na całkowicie zmyślone nazwisko „Tamarof”, łączące imię jego ukochanej, Temy Sznajderman, z końcówką tatarskiego nazwiska z okolic Wilna. Był jednym z założycieli Żydowskiej Organizacji Bojowej. Wszedł również w skład jej Komendy Głównej. W czasie wojny niejednokrotnie przekraczał granice Generalnego Gubernatorstwa: był między innymi w Wilnie, w Grodnie, w Krakowie, Będzinie, co ułatwiała mu jego przybrana tatarska tożsamość. W getcie warszawskim zaangażował się w wydawanie prasy konspiracyjnej („Jedijes”). Był również świadkiem Wielkiej Akcji 1942 roku. Jak wspomina Icchak Cukierman - bliski przyjaciel Tenenbauma - Mordechaj został mianowany „komendantem na Białystok”, gdzie miał za zadanie zorganizować podziemny ruch oporu, zjednoczyć działania różnych organizacji konspiracyjnych oraz przygotować getto do powstania i zbrojnej samoobrony ${ }^{5}$.

2 Ukucie tego terminu było owocem inspirujących rozmów z dr hab. Anną Michałowską-Mycielską, za co pragnę w tym miejscu podziękować.

3 Więcej na temat tego archiwalnego zbioru zob. A. Bańkowska, W. Romanik, Podziemne Archiwum Getta Białostockiego. Archiwum Mersika-Tenenbauma, „Zagłada Żydów. Studia i materiały" 2013, t. 9, s. 257-273.

4 Świadczą o tym pisemne i ustne relacje osób, które znały Tenenbauma, w tym Chawki Folman-Raban. Wywiad z Chawką Folman-Raban [Izrael, 2011]. Prywatne archiwum autorki.

5 Zob. I. Cukierman, Mordechai, chaweri [Mordechaj - mój przyjaciel], [w:] Dapim, 1984, s. 225. 
Tenenbaum przybył do Białegostoku w listopadzie 1942 roku. Tu stał się jednym z głównych organizatorów podziemia: stanął na czele tzw. Bloku B, prowadził negocjacje $\mathrm{z}$ wieloma grupami działającymi w getcie, a także założył tajne laboratorium chemiczne do produkcji materiałów wybuchowych. Ponadto pełnił funkcję łącznika między podziemiem a prezesem Judenratu, Efraimem Baraszem, z którym długo utrzymywał bardzo dobre, wręcz przyjacielskie relacje.

\section{Materiały źródłowe}

Pisma Tamarofa, na podstawie których zaprezentuję temat, powstały głównie w języku hebrajskim, z fragmentami w języku jidysz ${ }^{6}$. Jak wspomniałam, są to trzy materiały źródłowe: Dziennik Tenenbauma (prowadzony od 13 stycznia do marca 1943 roku) oraz dwa dodatkowe dokumenty, które można również traktować jako całość. Pierwszemu z nich autor nadał tytuł „Akcja” w Białymstoku (Ha, akcja” beBialistok), drugiemu zaś Hearot, co oznacza „przypisy, uwagi”, które stanowią uzupełnienie do tegoż pisma - zapiski te, przez wzgląd na ich charakter proponuję nazwać w polskiej terminologii Komentarzem ${ }^{7}$. Oba dokumenty koncentrują się przede wszystkim na pierwszej „akcji likwidacyjnej” w getcie białostockim, do której doszło między 5 a 12 lutego 1943 roku. Tenenbaum opisuje w nich część wydarzeń z dłuższej perspektywy czasowej. Powstały one już po zakończeniu „akcji”, najprawdopodobniej w drugiej połowie lutego 1943 roku$^{8}$.

6 Autor posługuje się również zwrotami, bądź pojedynczymi słowami z innych języków, między innymi z polskiego, niemieckiego i rosyjskiego.

7 W drugim i ostatnim hebrajskim wydaniu pism Tenenbauma, nadano dokumentowi Hearot (tu: Komentarz) tytuł Jeszcze o akcji (hebr. Od al haakcja). Zob. Dapim, 1984, s. 73.

8 Różni archiwiści i kopiści odczytywali datę, zapisaną na jednej z kartek w zbiorze, na dwa sposoby: jako 17 bądź 27 lutego 1943. Po analizie charakteru pisma w rękopisach Tenenbauma oraz rozważaniu szeregu okoliczności związanych z warunkami tworzenia tekstów przez Tamarofa, przychylam się do odczytania daty jako 27 lutego 1943. Nie oznacza to naturalnie, że oba dokumenty powstały tego samego dnia, jednak jest wysoce prawdopodobne, że stało się to w okolicach tej daty. Zob. Ha, akcja” beBialistok, AYV, M11/6. 


\section{„Akcja lutowa”}

W Białymstoku spodziewano się nadejścia „akcji wysiedleńczej”. Wszak od listopada 1942 roku do stycznia 1943 roku na terenie Okręgu Białostockiego miała miejsce tzw. „likwidacja prowincji” białostockiej, która polegała na koncentrowaniu ludności żydowskiej z mniejszych miejscowości w przejściowych obozach ${ }^{9}$. Stamtąd Żydzi byli wywożeni w zdecydowanej większości do obozów zagłady (Treblinka, Auschwitz). W tym okresie Białystok jeszcze uchronił się przed „akcją”.

Bez wątpienia „akcja lutowa” była jednym z najtragiczniejszych wydarzeń w historii białostockiego getta. Rozpoczęła się 5 lutego o 3.30 nad ranem i trwała 8 dni, do 12 lutego 1943 roku. Według relacji zawartej w Dzienniku Tenenbauma, początkowo Niemcy zażądali od Barasza wydania 17600 Żydów. Później nakazali dostarczenie trzech transportów po 2100 osób w każdym z nich - na tej liczbie stanęły rozmowy z Baraszem jeszcze przed rozpoczęciem „akcji”. Niemcy mieli się kierować spisami sporządzonymi przez Judenrat. Znajdowały się na nich między innymi rodziny, w których nikt nie pracował. Miała to być ofiara z kilku tysięcy osób, aby ocalić życie kilkudziesięciu tysiącom pozostałych mieszkańców getta - wszak sytuacja na froncie mogła każdego dnia ulec zmianie ${ }^{10}$.

W ostatecznym rozrachunku ,akcja” pociągnęła za sobą nie 6300, lecz około 10 tysięcy ofiar, w tym kilkaset osób zostało zamordowanych na miejscu ${ }^{11}$.

9 Szymon Datner używa określenia „likwidacja «prowincji» białostockiej”, stosując cudzysłów jedynie w przypadku ,prowincji”. Poszerzenie znaku interpunkcyjnego jest w tym miejscu celowym zabiegiem, wskazującym na opresyjną nomenklaturę niemieckich władz, która upowszechniła się również w polskojęzycznych badaniach historyków. Zob. S. Datner, Eksterminacja ludności żydowskiej w Okregu Białostockim, „Biuletyn Żydowskiego Instytutu Historycznego" 1966, nr 60, s. 24.

10 Według danych z Dziennika, na początku lutego 1943 roku w getcie białostockim znajdowało się około 42 tysięcy Żydów. Zob. Dziennik, [w:] Dapim, 1984, s. 38-39.

11 „Akcja” w Biatymstoku, [w:] Dapim, 1984, s. 72. Por. podsumowanie ,akcji” w raporcie Judenratu dla gestapoz2.04.1943, [w:] Dapim, 1984, s. 75-76. W marcu 1943 roku w getcie białostockim pozostało jedynie 31 tysięcy Żydów. Zob. S. Bender, „Akcja Reinhardt" w okręgu biatostockim, [w:] Akcja Reinhardt. Zagłada Żydów w Generalnym Gubernatorstwie, seria „Konferencje IPN”: t. 17, red. D. Libionka, Warszawa 2004, s. 214. 
Trzeciego dnia „akcji wysiedleńczej” Tenenbaumowi udało się spotkać z Baraszem, zaś wynik ich rozmowy podsumowuje krótko: „,[Barasz] nie ma prawie żadnego kontaktu z Niemcami. Przychodzą i robią swoje bez powiadomienia go o czymkolwiek"12.

Tysiące ludzi zgromadziło się w fabrykach, licząc na to, że tam będą bezpieczni. Według spisu przeprowadzonego piątego dnia „ewakuacji”, najprawdopodobniej przez działaczy i współpracowników podziemia, w fabrykach znajdowało się 12 tysięcy osób. Jeszcze więcej osób ukrywało się bardzo skutecznie na strychach, w piwnicach oraz w innych schronach - niektórzy tworzyli nawet barykady. „Całe getto w Białymstoku - [to] jedna wielka kryjówka”, zanotował Tenenbaum ${ }^{13}$.

Dziewiątego lutego w getcie pojawił się problem donosicieli, czyli już pochwyconych osób, które skuszone ofertą wypuszczenia na wolność w zamian za wskazanie kryjówek innych Żydów, pokazywały miejsca, o których Niemcy, bez ich wsparcia - jak pisze Tamarof - nigdy by się nie dowiedzieli. Takie osoby miały otrzymywać następnie oficjalne zaświadczenie, zwalniające $\mathrm{z}$ transportu w danym dniu w zamian za ,pomoc udzieloną przy ewakuacji Żydów z getta z Białegostoku"14. Tego samego wieczoru, którego zakończyła się „akcja lutowa”, doszło do pierwszych samosądów nad żydowskimi donosicielami. O podobnych przypadkach Tenenbaum informował jeszcze szóstego dnia po zakończeniu akcji (18.02.1943 r. $)^{15}$. Do linczowania dochodziło $\mathrm{w}$ tajemnicy przed Niemcami. Policja żydowska zaś „udawała, że nie widzi tego, co się dzieje”16. Warto zauważyć, że wątek donosicieli w relacji Tamarofa pojawia się dopiero piątego dnia ,akcji”, po tym jak Niemcy bezskutecznie usiłowali znaleźć kolejne ofiary do transportu i wpadli na pomysł przekupywania Żydów obietnicą szansy na życie. Analiza narracji pism Tenenbauma wskazuje na to, że brak jest wcze-

12 Tamarof notuje te słowa pod datą 7 lutego 1943 roku w dokumencie „Akcja” w Biatymstoku. Zob. Dapim, 1984, s. 68.

13 Tamże, 1984, s. 73. Wszystkie tłumaczenia w artykule z hebrajskiego oraz jidysz zostały wykonane przez autorkę niniejszego opracowania.

14 Wydaje się, że Tenenbaum przytoczył tekst niemieckiego dokumentu, zaś podane zdanie, w tym słowo „ewakuacja” stanowią z niego cytat.

15 Dapim, 1984, s. 47.

16 Tamże, s. 42. 
śniejszych informacji na temat podobnego zjawiska w jego świadectwach. Wydaje się, że to na pozór banalne spostrzeżenie często umykało innym badaczom tematu, być może z powodu zbyt emocjonalnego podejścia do tej bardzo drażliwej i bolesnej kwestii.

\section{Icchok Malmed}

Pisząc o „akcji lutowej” nie sposób pominąć postaci Icchoka Malmeda, który przez wielu został okrzyknięty bohaterem getta. Dziś jego imię nosi jedna $\mathrm{z}$ ulic $\mathrm{w}$ centrum Białegostoku ${ }^{17}$. Istnieją różne wersje opowieści o Malmedzie. W niniejszym opracowaniu skupiam się przede wszystkim na opisie Tenenbauma, który dodał nowe elementy do historii znanej z licznych świadectw. Moim celem nie jest weryfikacja informacji podanych w pismach Tamarofa. Zaprezentowane tu fragmenty jego relacji można traktować jako jeden z wielu głosów, w tym szczególnie istotny dla badań ze względu na gatunek świadectwa hic et nunc.

Nad ranem 5 lutego, w dzień rozpoczęcia „akcji”, do Tenenbauma dotarła informacja, że „jeden Niemiec, któremu wylano na oczy kwas, ze zdenerwowania strzelił, trafiając swego kolegę [innego niemieckiego żołnierza]"18. Stało się to w mieszkaniu na ulicy Kupieckiej 29. Ciało zabitego Niemca przyniesiono do Judenratu. Według relacji Tamarofa, w odwecie, z domu pod tym adresem oraz z budynków z nim sąsiadujących Niemcy zabrali 120 osób, które następnie rozstrzelano na ul. Szlacheckiej ${ }^{19}$. W dokumencie „Akcja” $w$ Biatymstoku Tenenbaum dodaje

17 W czasie wojny ulica nosiła nazwę „Kupiecka”. Na tej ulicy miał miejsce incydent związany z Malmedem, tutaj także doszło do egzekucji na nim trzy dni później, 8 lutego 1943 roku.

18 Informacja ta doszła do Tamarofa nad ranem 5 lutego 1943 roku i pochodzi z notatek spisywanych „na gorąco”. Zob. Dapim, 1984, s. 40.

19 Istnieją rozbieżności odnośnie do liczby rozstrzelanych osób, zaś adres podawany jest na różne sposoby. Większość źródeł i badaczy podaje informację o 100 ofiarach. Wieccej na ten temat zob. K. Stoll, Producing the Truth. The Bielefeld Trial and the Reconstruction of Events surrounding the Execution of 100 Jews in the Bialystok Ghetto following the 'Acid Attack', „Dapim. Studies on the Shoah” 2011, vol. 25, s. 1-54. Por. P. Kapłan, Zagłada Białegostoku. Luty 1943 r., „Biuletyn Żydowskiego Instytutu Historycznego" 1966, nr 60, s. 80 oraz S. Datner, Walka i zagłada białostockiego ghetta, Warszawa 2014, s. 51. 
informację: „Rano przybyła komisja dociec przyczyny śmierci Niemca. Ustalono, że kula nie pochodziła z niemieckiej broni”20.

Następnego dnia (6.02.1943, sobota), zgodnie z rozkazem władz, ukazało się ogłoszenie służby porządkowej:

„Malmed Abraham ${ }^{21}$, urodzony 1903, zamieszkujący na Kupieckiej 29 - każdy kto go odnajdzie lub o nim poinformuje, otrzyma nagrodę 10 tys. marek". Zabił Niemca.

Kolejnego dnia, w niedzielę, następuje przerwa w akcji. Według relacji Tenenbauma:

Abraham Malmed przyszedł i wydał się w ręce policji "aby uratować getto". W fabrykach - radość „Złapali Malmeda”. Przyszła komisja gestapo w celu śledztwa. [Pytają Malmeda ${ }^{22}$ ] „Czemu zabiłeś Niemca?” - „Ja was nienawidzę. Przepraszam, że zabiłem tylko jednego. Na moich oczach polegli moi rodzice. Na moich oczach zamordowaliście w Słonimiu 10000 Żydów. Nie żałuję [tego co zrobiłem]".

Tak miał odpowiedzieć Malmed. W swojej relacji Tenenbaum podaje niezwykle ciekawy szczegół, który nie jest powszechnie znany i ze zrozumiałych względów nie pojawia się w innych świadectwach. Otóż Tenenbaum przez cały dzień $\mathrm{w}$ niedzielę 7 lutego próbował dotrzeć do Malmeda, aby przekazać mu cyjanek, jeszcze przed oficjalną egzekucją. Jednak - jak stwierdził - nie było to możliwe. Nawet żydowskim policjantom nie pozwolono się do niego dostać23.

Dzień później, w poniedziałek 8 lutego o godzinie 8 rano miała nastąpić egzekucja Malmeda. Na wydarzenie przybyło podobno aż 300 przedstawicieli z różnych wojskowych jednostek (żandarmeria, gestapo i inni). Egzekucja opóźniła się o pół godziny, gdyż czekano na przybycie

20 Dapim, 1984, s. 66.

21 Najprawdopodobniej funkcjonował pod dwoma imionami: Icchok Abraham Malmed.

22 Dane w nawiasach kwadratowych stanowią uzupełnienie tłumaczki.

23 Dapim, 1984, s. 68. 
prominentnego nazisty. W tym czasie toczyła się dyskusja między Malmedem a pilnującymi go Niemcami, którą przywołał Tamarof w dokumencie „Akcja” $w$ Biatymstoku:

Malmed przepraszał, że zabił właśnie tego Niemca. Słyszał, że ten jeden był dobrym człowiekiem. Pytał czy pozostawił po sobie żonę, dzieci. Będzie się modlił - jeżeli B-g istnieje - za nich. On mówi, a oni go biją. Prosi o wodę - „Już nie potrzeba ci wody". Drwią z niego. Urągają mu. Umiera z godnością. Nie prosił, nie błagał. Spokojnie. Wisiał 48 godzin. Zerwał się sznur. Stał na chodniku jak żywy, prosto, w całej okazałości, przywiązany do sznura, aby się nie przewrócił.

Także w relacji Pesacha Kapłana z lutego-marca 1943 roku, zachowanej w podziemnym archiwum getta, pojawiła się informacja, że Malmed sam wydał się w ręce gestapo. Inni podają, że Malmeda wytropił Judkowski, agent gestapo ${ }^{24}$.

Od drugiego dnia „akcji”, tj. od 6 lutego, poszukiwania osób do wywózki odbywały się za dnia: rozpoczynały się około 6-6.30 rano, zaś kończyły około 5-6 popołudniu. Najwyraźniej po incydencie z Malmedem z pierwszego dnia „akcji” (05.02.1943 r.) żołnierze niemieccy bali się wchodzenia do mieszkań w ciemnościach. Również za dnia, gdy znaleźli żydowskiego policjanta, wysyłali go przed sobą, aby jako pierwszy wszedł do mieszkania - dopiero drugi w kolejności wchodził Niemiec z bronią gotową do strzału. Tamarof odnotował parę przypadków, gdy Żydzi ranili w takiej sytuacji żydowskiego policjanta zamiast niemieckiego żołnierza ${ }^{25}$.

\section{Policja żydowska w czasie „akcji lutowej”}

Policja żydowska przedstawiona jest w pismach Tenenbauma w bardzo korzystnym świetle. We wspomnianym Komentarzu, w którym autor oceniał „lutową akcję” z pewnej perspektywy czasowej, znajdujemy takie słowa:

24 Taką uwagę dodaje w przypisie redaktor relacji Pesacha Kapłana, zob. P. Kapłan, Zagłada..., dz. cyt., s. 81, przypis nr 9. Por. B. Mark, Ruch oporu w getcie białostockim. Samoobrona - Zagłada - Powstanie, Warszawa 1952, s. 161. Por. E. Rogalewska, Getto białostockie. Doświadczenie Zagłady - świadectwa literatury i życia, Białystok 2008, s. 94.

25 Dapim, 1984, s. 66. 
Białystok był jedynym miastem w granicach Polski gdzie policja żydowska - nawet ta część policji, która została zmuszona do brania w akcji aktywnego udziału tzn. do pójścia z siekierami i otwierania drzwi - stanęła na wysokości [zadania]. Nie donosili, nie pomagali Niemcom, „nie byli bardziej papiescy od papieża”. Nieraz z narażeniem życia - policjanci ratowali dziesiątki i setki Żydów w kryjówkach $^{26}$.

Gdy na kilka godzin przed rozpoczęciem akcji mieszkańcy zagrożonej dzielnicy zostali ostrzeżeni przez członków podziemia o nadchodzącym niebezpieczeństwie - przerażeni zaczęli się ukrywać. Tej nocy Tenenbaum „na gorąco” zapisywał w Dzienniku swoje obserwacje:

Kwadrans do drugiej w nocy. Setki ludzi krążą po ulicach, wędrując z miejsca na miejsce. Panika. Ukrywają się. Boją się każdego szmeru. Żydowscy policjanci rozmawiają między sobą o tym, że nie chcą brać udziału w akcji i przy najbliższej sposobności zrzucą swoje [policyjne] czapki ${ }^{27}$.

W dokumencie „Akcja” $w$ Biatymstoku, pod datą 5 lutego, Tamarof dopisał interesujące szczegóły:

Do siódmej nad ranem w całej dzielnicy Niemcy znaleźli do pięciuset Żydów. Zaczęli bić policjantów żydowskich, mówiąc, że to oni są temu winni. [Oskarżali ich o to, że] nie chcą szukać, [że] powiedzieli Żydom, aby się ukryli itd. Policjanci zaczęli uciekać z miejsca „akcji”. Jeszcze wcześniej, wielu policjantów nie przyszło na miejsce zbiórki. Nie chcieli brać udziału w akcji. Ukryli się ${ }^{28}$.

Tenenbaum rozważał, jak może wyglądać zachowanie policji żydowskiej w czasie kolejnej „akcji”, co do której miał pewność, że nadejdzie. Porównał getto białostockie do innych miejsc, w których postawiono policjantom warunek dostarczenia kontyngentu, tj. znalezienia wyznaczonej liczby osób do transportu, grożąc zarazem, że w razie

26 Tamże, s. 74.

27 Fragment napisany w nocy z 4 na 5 lutego 1943 roku. Zob. Dapim, 1984, s. 40.

28 Tamże, s. 65. 
niewykonania zadania sami policjanci, bądź też ich rodziny staną się ofiarami. W getcie białostockim nie zaistniała taka sytuacja. Tamarof kończy opis retorycznym pytaniem: „Może z tego powodu - wszystko poszło tak dobrze?"29

Badaczka Katrin Stoll przeciwstawia krytyczną ocenę zachowania żydowskiej policji, wyrażoną w świadectwie Szymona Datnera - łagodnej, a wręcz pozytywnej opinii Tenenbauma, którą podkreślała w swoich opracowaniach izraelska historyczka Sara Bender ${ }^{30}$. Wydaje się, że te dwa opisy stoją ze sobą w sprzeczności, jednak czy rzeczywiście tak jest? Również w relacji Tenenbauma policja żydowska nie znika całkowicie z horyzontu narracji, a jej udział w „ewakuacji” nadal trwa - choć najprawdopodobniej dotyczy jedynie części Ordnungdienst. Istotnie, zastanawiające jest dlaczego w Walce i zagładzie białostockiego ghetta Datner nie wspomina w ogóle o buncie policjantów - być może we wczesnym okresie powojennym, nie posiadał jeszcze więcej informacji na ten temat. Uważam jednak, że mimo pewnej rozbieżności, świadectwa Datnera oraz Tenenbauma wcale nie muszą siebie nawzajem wykluczać. Wręcz przeciwnie $-\mathrm{w}$ duecie poszerzają one perspektywę.

\section{Po ,akcji”}

Poruszający pozostaje tekst Tamarofa, który powstał dzień po zakończeniu akcji, tj. 13 lutego. Jest to najdłuższy fragment Dziennika zapisany ciągiem w języku jidysz, który przytaczam tu w całości:

Po „akcji”. Dopiero teraz widać pełnię grozy. Po wielu zaginął ślad; ludzie gnają przez miasto, nawołując swoich bliskich. Biegną i upadają, biegną i upadają. Wyciąga się z kryjówek uduszone dzieci - w czasie poszukiwań zaczęły płakać i chciano je uciszyć. Wszyscy gramolą się z paczkami. Wszędzie słychać płacz. Policjanci chodzą po piwnicach, strychach i wszelkich dziurach, gromadząc zwło-

29 Tamże, s. 74.

30 K. Stoll, O „Walce i zagładzie białostockiego ghetta” Szymona Datnera, [w:] Walka i zagłada biatostockiego ghetta, wyd. 2, Warszawa 2014, s. 102-103. Por. S. Bender, The Jews of Bialystok during World War II and the Holocaust, Waltham (Mass.) 2008, s. 203. 
ki. Mieszkania wypędzonych są opieczętowywane. Na cmentarzu ogromne stosy zmarłych, chowamy ich w masowych grobach. Jeden wielki płacz ${ }^{31}$.

Po lutowej „akcji deportacyjnej” rozniosła się wiadomość, że kolejna nastąpi 28 lutego ${ }^{32}$. W rzeczywistości tego dnia nie doszło do „ewakuacji”. 27 lutego odbyło się wewnętrzne posiedzenie członków kibucu Tel Chaj należącego do ruchu Dror, który miał swoją siedzibę w getcie białostockim. Zachował się dokładny protokół z tego zebrania, który przedstawia dyskusję członków ruchu nad dalszą strategią działania grupy ${ }^{33}$. Na spotkaniu, któremu przewodniczył Tamarof, debatowano nad dylematem: czy iść do lasu i stamtąd prowadzić walkę z Niemcami, czy też pozostać w getcie i skupić siły na przygotowaniu zbrojnego oporu zanim nastąpi kolejna akcja? ${ }^{34}$ Zdania były podzielone, jednak ostatecznie zwyciężyło stanowisko, aby w razie rozpoczęcia przez Niemców masowych deportacji, członkowie ruchu zainicjowali walkę, czyli tak zwaną „kontrakcję”.

\section{Podsumowanie}

W swoich pismach Tamarof w niezwykle szczegółowy sposób opisuje wydarzenia z lutego 1943 roku, swoje spotkania, przeżycia, refleksje, codzienną aktywność. Dokumenty te odkrywają przed czytelnikiem sprawy i informacje, które znane były tylko nielicznym, na przykład poufne dane otrzymywane od prezesa Judenratu bądź strategie i politykę różnych podziemnych organizacji w getcie.

31 Dapim, 1984, s. 41.

32 Wskazują na to zapiski Tamarofa w Dzienniku z 19 lutego 1943 roku. Zob. Dapim, 1984, s. 51.

33 Oryginalny protokół powstał w języku jidysz. Dokument ukazał się również w polskim tłumaczeniu, zob. Sprawozdanie z ogólnego zebrania aktywu kibucu Tel-Chaj w Biatymstoku z 27 lutego 1943, „Biuletyn Żydowskiego Instytutu Historycznego” 1966, nr (60), tłumaczenie z jidysz A. Rutkowski, s. 91-97. Warto dodać, iż to sprawozdanie stało się dokumentem reprezentującym białostocki wątek na wystawie głównej w muzeum Yad Vashem w Izraelu.

34 Więcej na temat tej dyskusji zob. W. Romanik, Co czytano $w$ czasie Zagłady? Refleksja nad powieścia „Czterdzieści dni Musa Dah” w kontekście żydowskiego ruchu oporu, „Studia Judaica” 2017, nr 2 (40), s. 209-235. 
Na narrację świadectw Tenenbauma z pewnością miał wpływ fakt, iż ich autor posiadał bogate doświadczenie w podziemnej działalności również w innych gettach, a także obszerną wiedzę na temat życia żydowskich społeczności w różnych zakątkach Generalnej Guberni oraz Rzeszy Niemieckiej ${ }^{35}$. O wartości historycznej pism Tenenbauma świadczy również fakt, iż fragmenty jego Dziennika posłużyły jako dowód rzeczowy w procesie Ericha Kocha ${ }^{36}$. Niewątpliwie pisma Tenenbauma są bardzo cennym materiałem źródłowym, którego nie sposób ominąć opisując życie i zagładę Żydów z białostockiego getta.

\section{Bibliografia}

Bańkowska Aleksandra, Romanik Weronika, Podziemne Archiwum Getta Białostockiego. Archiwum Mersika-Tenenbauma, "Zagłada Żydów. Studia i materiały” 2013, t. 9, s. 257-273.

Bender Sara, „Akcja Reinhardt” w okręgu białostockim, [w:] Akcja Reinhardt. Zagłada Żydów w Generalnym Gubernatorstwie, seria „Konferencje IPN”: t. 17, red. Dariusz Libionka, Warszawa 2004.

Bender Sara, Mul mawet orew. Jehudei Bialistok bemilchemet haolam hasznija, Tel Awiw 1997. [wydane również w wersji angielskiej pt. The Jews of Bialystok during World War II and the Holocaust, tłum. z hebr. Yaffa Murciano, Waltham (Mass.) 2008. Publikacja została udostępniona częściowo w projekcie Google Books.].

Blumental Nahman, Darko szel Yudenrat - teudot mi-geto Bialistok, Jerozolima 1962.

35 Zdobywał ją między innymi dzięki rozmowom z łącznikami podziemia. Icchak Cukierman napisał o Tenenbaumie: „Zwykł spotykać się ze wszystkimi łącznikami powracającymi z najbardziej odległych zakątków Generalnej Guberni oraz Rzeszy niemieckiej - zbierając wszystkie wieści dotyczące życia żydowskich społeczności.” Zob. I. Cukierman, Mordchai, chaweri, [w:] Dapim, 1984, s. 221.

36 Archiwum Głównej Komisji Badania Zbrodni przeciwko Narodowi Polskiemu, SWWW, 742780, Akta procesu Ericha Kocha, t. IX. Źródło za: Ewa Rogalewska, Getto białostockie. Doświadczenie Zagłady - świadectwa literatury i życia, Białystok 2008, s. 50. 
Cukierman Icchak, Mordechai, chaweri, [w:] Dapim min hadleka. Mahadura chadasza, metukenet umurchewet, red. Bronka Klibanski, Cwi Szner, Izrael 1984.

Datner Szymon, Eksterminacja ludności żydowskiej w Okręgu Białostockim, „Biuletyn Żydowskiego Instytutu Historycznego" 1966, nr 60, s. 3-50.

Datner Szymon, Getto białostockie i jego podziemne archiwum, [w:] Studia i materiały do dziejów miasta Białegostoku. Praca zbiorowa, t. II, red. Jerzy Antoniewicz i Jerzy Joka, Białystok 1970, s. 93-112.

Datner Szymon, Walka i zagłada białostockiego ghetta, Łódź 1946. [Krytyczne wydanie publikacji ukazało się nakładem wydawnictwa Żydowskiego Instytutu Historycznego, w Warszawie w 2014 roku].

Kapłan Pesach, Zagłada Białegostoku. Luty 1943 r., „Biuletyn Żydowskiego Instytutu Historycznego" 1966, nr 60.

Klibanski Bronka, Al Mordchai weal archeono, [w:] Dapim min hadleka, Izrael 1984, s. 205-215.

Klibanski Bronka, Ariadne, Tel Awiw 2002.

Mark Bernard, Ruch oporu w getcie białostockim. Samoobrona - Zagłada - Powstanie, Warszawa 1952.

Rogalewska Ewa, Getto białostockie. Doświadczenie Zagłady - świadectwa literatury i życia, Białystok 2008.

Romanik Weronika, Co czytano w czasie Zagłady? Refleksja nad powieścią „Czterdzieści dni Musa Dah" w kontekście żydowskiego ruchu oporu, "Studia Judaica” 2017, nr 2 (40), s. 209-235. Dostępne przez: http://www.ejournals.eu/SJ/2017/ Numer-2-40/art/11469/ [dostęp: 21.06.2018 r.].

Sprawozdanie z ogólnego zebrania aktywu kibucu Tel-Chaj w Białymstoku z 27 lutego 1943, „Biuletyn Żydowskiego Instytutu Historycznego” 1966, nr (60), tłumaczenie z jidysz Adam Rutkowski, s. 91-97.

Stoll Katrin, O „Walce i zagładzie białostockiego ghetta” Szymona Datnera, [w:] Szymon Datner, Walka i zagłada białostockiego ghetta, wyd. 2, Warszawa 2014, s. 91-107.

Stoll Katrin, Producing the Truth. The Bielefeld Trial and the Reconstruction of Events surrounding the Execution of 100 Jews in the Bialystok Ghetto following the 'Acid Attack', „Dapim. Studies on the Shoah” 2011, vol. 25, s. 1-54.

Studia i materiały do dziejów miasta Białegostoku. Praca zbiorowa, t. II, red. Jerzy Antoniewicz i Jerzy Joka, Białystok 1970.

Tenenbaum Mordechaj, „Akcja” w Białymstoku, Archiwum Yad Vashem M11/6. 
Tenenbaum Mordechaj, Dapim min hadleka. Mahadura chadasza, metukenet umurchewet, red. Bronka Klibanski, Cwi Szner, Izrael 1984.

Tenenbaum Mordechaj, Dapim min hadleka. Pirkei joman, michtawim ureszimot meet Mordechaj Tenenbojm-Tamarof, Tel Awiw 1947.

Tenenbaum Mordechaj, Dziennik Mordechaja Tenenbauma, Archiwum Yad Vashem $\mathrm{M} 11 / 4, \mathrm{M} 11 / 5$.

Tenenbaum Mordechaj, Komentarz, Archiwum Yad Vashem M11/6.

Tenenbaum-Baker Nina, Gibor hagetaot. Mordchai Tenenbaum-Tamarof, Tel Awiw 1980.

Wywiady autorki z Chawką Folman-Raban [Izrael, 2011-2012], prywatne archiwum autorki. 